\title{
Face, Posture, and Gesture (Study of Kinesik Aspects in Qur'an)
}

\author{
Fairus $^{1,3}$, Syukur Kholil ${ }^{2}$, Zainal Arifin ${ }^{2}$ \\ ${ }^{1}$ PhD Student in Islamic University of North Sumatera (UINSU), Medan, Indonesia \\ ${ }^{2}$ Lecture in Islamc University of North Sumatera (UINSU), Medan, Indonesia \\ ${ }^{3}$ Lecture in Islamic University of Ar-Raniry (UIN Ar-Raniry), Aceh, Indonesia \\ tgkdrsaiful@gmail.com
}

\begin{abstract}
Until now there has been no research result that comprehensively analyzes the relationship between the Qur'an and kinesik aspects as part of the realm of nonverbal communication. In fact, besides loading many terms regarding verbal communication, the Qur'an also gives a signal about the reality of nonverbal communication. One of the signs is enshrined in the Surah asa Abasa / 80 verse 1 as a Makkiyah category. The verse tells of the nonverbality of communication that Muhammad committed against a blind man named 'Abdullah Ibn Ummi Maktum. The codification carried out by the Qur'an on the events of the past 14 centuries shows the magnitude of the Qur'an's attention to nonverbal aspects, especially kinesik, in human life. Therefore, in addition to the Surah / Abasa / 80 verse 1, it is assumed that there are also other verses that contain kinesik content both facial, gestural, and postural in the Holy Qur'an. Based on this, this study was conducted to identify which verses were revealed to Muhammad who talked about kinesik and how the verses were relevant to the development of scientific communication. From the results of the research carried out qualitatively with mix-method patterns that combine reference research (library research) and text analysis (content analysis) with thematic interpretive approaches (maudu'iy) it was found that the verses of the Qur'an which describe the communication process explicitly illustrates that potential kinesic aspects occur throughout the period in the process of human interaction. The Al-Qur'an contains information about kinesik processes that occur spontaneously, naturally, and conditionally. This shows that the presentation of kinesik verses is relevant to proceed in the global era, even throughout modern human life.
\end{abstract}

Keywords: Kinesik; Al-Qur'an; posture; face

\section{Introduction}

Although more than half of the social meanings in the communication process are obtained from nonverbal aspects, especially in the form of face-to-face involving faces, postures, and gestures, not many scientific articles look at the nonverbal aspects and their relevance to the Qur'an. Various books and research reports produced so far tend to emphasize the main discussion on the terms of the Qur'an on the verbal dimensions of ansich.

The lack of information about nonverbal studies in the context of the Holy Qur'an is also seen from various textbooks used in the lecture process. Books on Islamic communication that are used by many Islamic religious college students in Indonesia, both undergraduate, master, and doctoral strata, do not allude to nonverbal communication based on a comprehensive Qur'anic perspective. Various discussions about nonverbal communication often refer to the arguments and research results of Western scientists, especially Europe (Germany), Australia, and the United States. Islamic aspects, both verses or hadith, are often only justifiers of the arguments of the results of the research. Therefore, it is not surprising that many scientific papers produced by Islamic communication study 
students tend to be paradigmatic in the West so that the works do not appear to stand above the perspective of the Qur'an. Verses and hadith, once again, are only used as labeling and support for opinions that have existed.

Within certain limits, a number of researches and books published in the public domain have succeeded in carrying out the discourse of communication Islamization. However, as alluded to at the beginning of this paper, the book and research tend to emphasize the discussion on Ansikh's verbal aspects. Nonverbalitas communication contained in the main source of Islam __ in this case the Qur'an _ _ tends to be marginalized. In fact, besides a number of terms relating to verbal communication, the Qur'an also cites nonverbal communication. One of a number of verses containing this, for example, is in the initial fragment of the Surah urah Abasa / 80. The clause in the category of Makkiyah_ that is the verse of the Qur'an which came down before this hijrah event, has a very thick communication content, even deliberately revealed as a correction and God's rebuke of the Prophet's (Muhammad) unethical behavior when communicating nonverbally.

In the study of nonverbal communication, changes in facial expressions and gestures that have meaning are called kinesik (kinesics). This term originates from the word kinesis

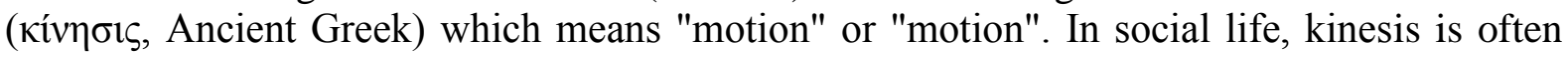
matched with the term body language. According to anthropologist Ray L. Birdwhistell who introduced this terminology for the first time in 1952, kinesik was part of nonverbal communication based on the movement of three aspects of the body, namely; facial, gestural, and postural. The message Muhammad showed against ullah The name of Ibn Ummi Maktum in the above case is the kineine physical nonverbal message in the facial realm.

From a number of things mentioned above it can be seen that since the 14th century ago the Qur'an gave a signal about nonverbality in human communication. In addition to the Surah asa Abasa / 80 verse 1, it is alleged that there are still other Makkiyah verses which contain content about kikaik both facial, gestural, and postural in the source of reference for Muslims. Because of that, this study intends to identify which verses were revealed to Muhammad who talked about kinesik and how the verses are relevant to the development of scientific communication.

\subsection{Kinesik}

\section{Review of Literature}

There are many nonverbal messages that have been classified by experts according to their respective perspectives such as, kinesik, parabaha-sa, space, time of artifact, smell and others. Of all the studies of nonverbal communication, the most widely known is the study of physics or body language. Body movement is a nonverbal behavior in which communication occurs through the movements of a person's body or body parts. Body movements include eye contact, facial expression, gestures, postures or gestures, and touch. Each time talking to other people from the spoken speech is complemented by body language both consciously and unconsciously. There is a personal developmental value that can be gained from developing the ability to use body language, as well as in developing other personal abilities. But this value will be greater if it can bring higher communication effectiveness seen from contributions to personal development and exploitation of human potential. Full language has a very important role in self presentation and sanity management.

In Communication: An Introduction, Deddy Mulyana stated that kinesik was a term coined by a pioneer in the study of nonverbal languages, Ray L. Birdwhistell. In this sense, 
every limb like the face, hands, feet and even the body as a whole, is considered to be used as a symbolic sign. In addition, in another book, Deddy also stated that gestures, body movements, body posture, head movements, facial expressions, and eye contact are behaviors that are all called body language that contain very potential meanings.

\subsection{Kinesik Forms}

Consciously or not, the human body provides many signals in the process of interaction. Referring to one of the kinesik meanings, namely the movement of the body which includes eye contact, facial expressions, gestures, posture or rawness, and touch, the classification of body language specifically and its explanation in detail are as follows:

\section{a. Facial expressions.}

It is undeniable that facial expressions have a big contribution in the ongoing communication process, someone's emotions are usually illustrated through the face, this is sometimes difficult to cover because faces tend to give signs spontaneously. the signals given by the face have many meanings that can help a person to achieve a good level of interaction and communication.

Often the face is the first part of someone who is seen when communicating. So that various kinds of facial expressions are widely used in greeting meetings. Facial expressions have great power in control in the type and quantity of communication that takes place between audiences. Birdwihistell estimates that there are 250,000 possible expressions on the face. The face is a clue to understanding one's emotions, the expression on one's face that is displayed can be estimated to be synonymous with joy, drought, hatred, fear, admiration, wonder, shock, nervousness, humiliation, sadness and a number of other feelings. smiles, glares, cheeks, sullen faces, grim faces, and so on are not just the implications of the movement of the muscles, but indicate hidden feelings or intentions of someone who is often not realized by the culprit.

\section{b. Eye contact}

A lot of literature says that the eye is a part of the face that gives a lot of cues and is the most powerful in the process of communication. Among the body parts found on the face of the eye are considered the most expressive. Although physically the human eye looks similar, but very many different meanings are reflected in someone's eyes in different situations. Eye contact which refers to the eyes or gaze is how and how much or how often we look at someone in the communication process. Eye contact conveys many meanings. This shows whether someone is paying attention to his interlocutor. Besides that, eye contact also conveys a series of emotions such as anger, fear, or affection. Although the amount of eye contact differs from one person to another, and from one situation to another, the results show that speakers can survive eye contact around 40 percent of the time talking and as much as 70 percent hear from the conversation.

\section{c. Smile}

A smile is a body language signal through facial expressions that are universally interpreted as manifestations of liking, but in certain conditions a smile also has different meanings depending on the situation and conditions during communication, there is even a cynical smile, a smile that is a smile and so forth.

When smiling the facial muscles such as zygomatic pull the corners of the mouth up in a smile, and other muscles like a corrigator, which pulls the eyebrows together in the face that supports them. The facial muscles are activated by the face raf. Sometimes people smile because they are happy, but they can also smile in different moods. 
d. Gesture

Gesture (gesture) is the movement of the hands, arms, and fingers that are used to explain or confirm. If a communicator says "about as high as this" or "almost as well as this" then the communication hopes to see gestures following a verbal explanation. Humans are different in using the number of gestures used to follow verbal words. There are people who "talk" with their hands far more than others. Gerard Nierenberg and Henry Calero suggest that gestures or gestures are used to express various things, including forgiveness, endurance, readiness, reassurance, frustration, self-confidence, fatigue, acceptance, hope, relationship, and suspicion.

Gesture can also be understood as the movement of the body, head, hands and feet which is intended to convey a certain impression. Gesture has an important role in communication because it can be a substitute and complete verbal language. Gesture is a monopoly of symbols in low-level communication in all cultures. Everyone can channel a lot of communicative data from head movements. For example, if someone asks, the tires can use a shake of the head instead of the word no or shake your head with the word no.

\section{e. Touch}

Touch or touch is formally known as haptics. Touch is placing part of the body in contact with something. This is the first form of nonverbal communication experienced by humans. For toddlers, touch is the first tool for receiving messages of love and comfort. Touching behavior is a fundamental aspect of nonverbal communication in general and about self-introduction in particular. Through God, humans communicate various kinds of emotions, feelings, and messages to others. Touch is also understood as a sign symbolized by the body.

\section{Research Methods}

This research is qualitative in nature, patterned mix-methods that combine reference studies (library research), text analysis (content analysis) with the approach of thematic interpretations (maudu'iy) that are rationalistic, abstractive, simplified; and observation (observation) of the human perpetrators of kinesik as objects that are not text so as to enable rational interpretation of the object of study. On the basis of that qualitativity, referring to Strauss and Corbin in Ros-yadi Ruslan, which states that qualitative research as a type of research whose procedure for finding results does not use statistical mechanisms or quantification, ${ }^{1}$ various things in this study will be explained through data collection descriptive without static formulas and symbols. The most emphasized thing here is the quality of the data, not the number of data. In addition, relevant to the object under study, the qualitative aspect is deliberately chosen in research because the nature of qualitativity that seeks to explain reality uses descriptive descriptions in the form of sentences, not numbers. This is the antithesis of the quantitative approach. If quantitative is very measurable and objective, the measurement of qualitative approaches that use sentence descriptions is subjective and can be discussed.

The primary data of this study is the Holy Qur'an. Secondary data was obtained from the Fi Zhilalil Qur'an interpretation by Sayyid Quthb, Tafsir Ibn Kathīr by 'Abd Al-Fida Ismā'il Ibn Kathīr Al-Dimashqi, and Tafisr Al-Misbah by M. Quraish Shihab. Included in

\footnotetext{
${ }^{1}$ Rosyadi Ruslan, Metode Penelitian Public Relation dan Komunikasi (Jakarta: Raja Gra-findo Persada, 2004), p. 213.
} 
this second category are the Qur'an and its translation published by the Quran Interpreter Foundation Organizer of the Ministry of Religion of the Republic of Indonesia, Anatomy of the Body in the Qur'an: Classical Thematic Interpretation by Syamsuddin Muhammad Ibn Abi Bakr, Book of Hadith Nine Imams, articles, and books that contain information, issues, and ideas about nonverbal communication.

\subsection{Kinesik Verses}

\section{Discussion}

There are a number of verses in the Qur'an that explicitly or implicitly indicate kinesik matters, including the face, posture, and gestures of the communicator. The verses are:

1. Al-Baqarah Verse 144 (raising your face to the sky)

"Indeed, we (often) see your face looking up to the sky, so really we will turn you to the qibla that you like. turn your face in the direction of the Grand Mosque. Every where you are, turn your face on him. and indeed the people (Jews and Christians) who were given the Book (the Torah and the Gospel) did know, that turning to the Holy Mosque was true of their Lord; and God is not unaware of what they do. "

\section{Al-Baqarah Verse 267}

"O ye who believe, spend (in the way of Allah) some of the results of your good efforts and part of what we remove from the earth for you. and do not choose bad things, then spend it from you, even though you yourself do not want to take it, but by turning your eyes on it. and know, that Allah is rich, praiseworthy. "

\section{Al-Anfal Verse 35 (clapping)}

"Their prayers around the Temple, others are not just whistles and clapping hands. Then feel the punishment because of your disbelief. "

\section{Hud verse 81 (turned)}

"The messengers (angels) said:" O Luth, verily we are the messengers of your Lord, they will not be able to disturb you, so go with your family and followers at the end of the night and no one among you who are left behind (except), except your wife. Surely the punishment that befalls them will be overwritten. Indeed, when the fall of the punishment on them is at dawn, isn't it near dawn?"

\section{Yusuf Verse 99 (embracing)}

"So when they entered Joseph's place: Joseph put his arms around his father ${ }^{2}$ and he said:" Enter into the land of Egypt, God willing, it is safe. "

\section{Ibrahim Verse 42 (wide-eyed)}

"And do not you (Muhammad) think that Allah is negligent of what wrongdoers do. Verily, Allah gave them respite until the day that at that time (their) eyes widened. "

7. Ibrahim Verse 43 (eyes do not blink)

\footnotetext{
${ }^{2}$ His mother's father and sister (aunt).
} 
"They came hurrying to fulfill the call by lifting their heads, while their eyes were not blinking and their hearts were empty."

\section{Al-Hijr verse 65 (turned)}

"Then go away at the end of the night with your family, and follow them from behind and let no one of you turn back and continue the journey to the place you are commanded."

\section{An-Nahl Paragraph 58 (black face red)}

"And when someone of them is told by (the birth of) a daughter, her face is black, and she is very angry."

"And if someone of them is given the news of (the birth of) a daughter, black face is red." Because she feels very sad over the misery they receive. "And he was very angry." In a state of silence because of the profound sadness he felt. ${ }^{3}$

\section{Al-Isra Verse 51 (nodding his head)}

"Or a creature from a creature that is not possible (alive) according to your mind". Then they will ask: "Who will bring us back?" Say: "Who created you the first time." Then they will nod their heads they told you and said: "When will it (happen)?" Say: "Hope that time will rise near".

\section{Al-Kahfi Verse 42 (turning back and forth)}

"And his wealth is destroyed; then he turned his hands over and regretted what he had spent for it, and the vine collapsed with his parishioners and said: "It is wonderful that I did not associate anyone with my Lord."

\section{An-Naml Paragraph 19}

"So he smiled with a laugh because (hearing) the ant's words. and he prayed: "O my Lord, give me inspiration to continue to thank you for the blessings that you have given me and to two mothers, my father and to do righteous deeds that you are pleased with; the right thing. "

\section{Maryam Verse 29 (pointing)}

"So Maryam pointed to her son. they said: "How are we going to talk to a little kid who is still swinging?"

14. Al-Ahzab Verse 19 (looking with the eyes reversed)

"They cheat on you, when fear comes (danger), you see them looking at you with your eyes turned upside down like someone who fainted Because they will die, and when fear is gone, they chide you with a sharp tongue, they are cheating for do good. they are not believers, so Allah abolishes the reward. and that is easy for God. "

15. Az-Zumar Verse 60 (blackened face)

\footnotetext{
${ }^{3}$ Abdullah bin Muhammad, Tafsir Ibnu Katsir, Jilid 5. P. 156
} 
"And on the Day of Judgment you will see those who lie to God, their faces blackened. is it not in hell that there is a place for those who boast. "

\section{As-Shura Verse 45}

"And you will see them faced with hell in a state of submission. Because they feel contemptible, they see with a lethargic view. and those who believe say: "Those who lose are those who have lost themselves and (lost) their families on the Day of Judgment. Remember, verily the wrongdoers are in eternal doom."

\section{Az-Zukhruf verse 17}

"Even if one of them is given good news with what is made as an example for the Most Gracious God as something very strange; be a black face while he is very sad. "

\section{Al Qamar Verse 7}

"While lowering their views they came out of the graves as if they were flying grasshoppers."

19. Al Mulk verse 4

"Then look once again that your vision will return to you by not finding anything in your view that is exhausted."

20. Al Muluk verse 27

"When they saw the punishment (on the Day of Judgment) was near, the faces of the disbelievers were grim. and said (unto them) this (doom) that you used to ask for."

\section{Al-Qalam verse 51}

"And indeed those who disbelieve really almost derail you with their eyes, when they hear the Qur'an and they say:" Truly he (Muhammad) is truly a madman. "

\section{Al-Ma'arij verse 44}

"Their views are bowed down (as well) filled with humiliation. That's the day that was threatened with them. "

23. Al-Muddatstsir verse 22

"After that, he faces and frowns."

24. Al-Qiyamah Verse 7

"Then when the eyes widen (fear."

25. Al Qiyamah Verse 22

On that day the faces (the believers) are radiant.

26. Al Qiyamah verse 24

And the faces (of the unbelievers) were gloomy that day

27. Al Insan paragraph 10 

difficulties."

"Surely we fear the (doom) of our Lord one day (on that day) surly people are full of

\section{Period verse 1}

"He (Muhammad) was surly and turned away."

29. Ages verse 38

"Many faces on that day are radiant"

30. Abasa Verse 40

"And many faces on that day are covered with dust."

31. Al Muthaffifin Verse 24

"You can know from their faces their pleasures are full of pleasure."

32. Al Mutaffifin Paragraph 30

And if those who believe before them, they wink at each other's eyes.

33. Al Ghasyiah Verse 2

"Many faces that day are subject to humiliation."

34. Al Ghasyiah Verse 8

"Many faces on that day are radiant"

35. Al Fath verse 29

"Muhammad is a messenger of Allah and the people who are with him are harsh against unbelievers, but love their fellow humans. You see them bowing and prostrate for God's grace and pleasure, their signs appear on their faces from prostration. ${ }^{4}$ Such are their characteristics in the Torah and their characteristics in the Gospel, that is, like plants that give birth to their buds, so that the shoots make the plant Strong, and they become great and perpendicular to the point; the plant is pleasing to the planters because God wants to irritate the hearts of unbelievers (with the power of believers). God promises those who believe and do righteous deeds among them forgiveness and great reward. "

\subsection{Contemporary Thematic Interpretation of Kinesik Verse}

\section{Abasa (surly)}

One example of kinesic communication that is related to aspects of the face, posture, and gesture is included in the Surah asa Above verse 1 through verse expressions which mean "He (Muhammad) is surly and turned away,"

The main theme of this letter is the teaching of Muhammad. Comparing the ranks of interest so as not to give priority to something which was initially important to others who were similar to it or more important than it, while hinting at the differences in the conditions of the polytheists who turned their backs on Islam. great for the teachings of Islam. The word abasa means frowning or gloom. The verse above according to many scholars came down concerning the attitude of the Prophet to his companion 'Abdullah Ibn Ummi Maktum, when

\footnotetext{
${ }^{4}$ That is to say: in their faces they see the faith and sanctity of their hearts.
} 
the Prophet Muhammad s.a.w was busy explaining Islam to the idolaters of Mecca. The main figure is al-Walid Inb al-Mughirah. He hopes his invitation can touch their hearts and minds so that they are willing to embrace Islam and have a positive impact on the development of Islamic da'wah. These moments came Abdullah Ibn Ummi Maktum who did not know the Prophet's important activities and then interrupted the Prophet's conversation by asking to be taught to him what Allah taught the Prophet. Abdullah's attitude was not pleasing to the Prophet's heart, but he did not rebuke or rebuke him, but only appeared on his face, feeling displeased, so the surah asa Abasa came down as a rebuke to the Prophet.

2. Tabassama (smile)

The communication of body language in this verse is the expression on the face of Prophet Sulaiman when he heard the communication of the ant forces in a valley. In Q.S anNaml Verse 19, Allah says with meaning "So he smiled with a laugh Because (hearing) the words of the ant. and he prayed: "O my Lord, give me inspiration to continue to thank you for the blessings that you have given me and to the two mothers of my father and to do righteous deeds that you are pleased with, and enter me with thy mercy in the ranks of your servants the righteous. ${ }^{5}$ Sayyid Qutb explained that the verse above pertains to the events of the army of ants as stated in the previous verse, namely Q.S an-Naml verse 18; "Until when they reach the ant valley, an ant says: $O$ ants, enter into your nests, so that you will not be trampled by Sulaiman and his army, while they are not aware."

The word tabassama means to smile, while the word dhahikan means to laugh. This last word is more general than the word smile. A smile is a voice of expressive laughter without sound to show pleasure or joy by developing perfunctory lips. While laughter starts from smiles to those accompanied by sounds from the small to the loud sounds of explosions through the appliance, because of senag, happy to be amused. Therefore, every laugh contains a smile.

3. Ashath (pointing)

This verse describes one example of body language communication in the form of gestures in the form of hand movements. Allah SWT said in the letter Maryam verse 29: So Maryam pointed to her son. they said: "How are we going to talk to a small child who is still in a swing?"6

Maryam who heard the accusations of her people remained calm then according to the instructions she received, then she pointed to her child as saying "ask this child, he will explain to you sitting on the issue, then the people say" how do we talk to little children who are still swinging? He said, namely Isa as, who at the time was still a baby, who was enshrined next, said Isa: "Surely I am a servant of Allah, he gave me the Book (the Gospel) and he made me a prophet."

The word asyāra means to imply. ${ }^{7}$ This verse tells the story of the birth of the son of Mary without a father, Mary was criticized by her people who considered her to commit a major sin and get pregnant without marriage. His criticism was getting louder considering he was from the descendants of the Aaron family. The signal referred to in this verse is when Maryam refers to her child. The story in this letter contains a reaction in firm and profound attitudes, especially in the story of Mary and the eloquence of the Prophet Isa. Maryam prides

\footnotetext{
${ }^{5}$ M. Quraish Shihab, Tafsir Al-Misbah...Volume 10, p. 206

${ }^{6}$ M. Quraish Shihab, Tafsir Al-Misbah...Volume 8, p. 177.

${ }^{7}$ Muhammad Yunus, Kamus Arab Indonesia, (Jakarta: PT. Mahmud Yunus Wa Dzurriyah, 2010), p. 42.
} 
herself and rejects anyone who denies her actions. Then he was silent and signaled to the people who insulted him with various allegations to ask about his secret to his son.

4. Taqalluba wajhika Fissamā '(your face looks up to the sky).

This is one example of a verse that describes the terms of communication of the body language of the Prophet Muhammad s.a.w which fall into the category of gesture in the form of head movements. In the Qur'an the letter al-Baqarah verse 144 Allah SWT said: "Indeed we (often) see your face looking up into the sky, so really we will turn you to the qibla that you like. turn your face toward the Holy Mosque. and wherever you are, turn your face towards him. and indeed the people (Jews and Christians) who were given the Book (Torah and the Gospel) did know, that turning to the Holy Mosque was true of their Lord; and God is not unaware of what they do. "

5. Antughmidhū (squinting).

The expression of body language communication in this verse takes the form of eye behavior, Allah gives a parable of aversion and displeasure through the sign of one part of the human face, namely the eye, in Q.S. al-Baqarah verse 267 Allah SWT says: "O ye who believe, spend (in the way of Allah) a portion of the results of your good efforts and part of what we remove from the earth for you. and do not choose bad things, then spend it from you, even though you yourself do not want to take it, but by turning your eyes on it. and know, that Allah is rich, praiseworthy. "8

6. Wajhuhū Muswaddan (black; red faces)

Allah SWT explained the emotional condition of the Mushrikah Jahiliyah when they were blessed with daughters. Their emotional condition is explained by body language signals that appear from their faces. Allah SWT said in Q.S An-Nahl verse 58: "And when someone of them was told with (the birth of) a daughter, his face was black, and he was very angry." 9

The word aswada means black, this verse states one of the many bad habits of the Mushrikin, such as the beliefs of the tribe of Khuza'ah and of the times of Jahiliyah. They believe God has a daughter while they like boys. When someone of them was told about the birth of a daughter, they received the news in disgust and a disheveled face so that it was black with red face, and she was very angry. As the phrase "wajhuhū muswaddan (black; red faces). The word kazhīm means to hold back, meaning that he is holding back the anger over the delivery of the news which he thinks is bad. He was not only upset or angry but also so embarrassed that he hid himself from the crowd, because of their assumption about the bad news that was told to him. At that time he was really confused about what he would do with the daughter who was born, whether he would take care of him by bearing humiliation or would hide it in the ground alive.

Red and black face, caused by the burden of grief and harboring anger, as if a disaster was befalling him. In fact, a woman's child is a gift from God for her, as a boy too. Humans do not have the power to form children in the womb as women or men, he also could not blow life into the fetus, and he was not able to make simple sperm as a perfect human being. 7. Watarāhum yu'radhūna 'alaihā khāsyi'īn (seeing them facing hell in submission).

This verse describes the condition of the wrongdoers on the Day of Judgment. God describes the misery, humiliation and kept feeling that they feel through their body language signals in the form of postures or attitudes down when faced with hell. Allah SWT said in the

\footnotetext{
${ }^{8}$ M. Quraish Shihab, Tafsir Al-Misbah...Volume 1, p. 576.

${ }^{9}$ M. Quraish Shihab, Tafsir Al-Misbah...Volume 7, p. 258.
} 
letter of ash-Shurā verse 45: "And you will see them faced to hell in a state of submission because of (feeling) contemptible, they see with a listless look. and those who believe say: "Those who lose are those who have lost themselves and (lost) their families on the Day of Judgment. Remember, verily the wrongdoers are in eternal doom."

This verse tells about the situation of the wrongdoers who are astray with the humiliation and loss that awaits them. The wrongdoers are tyrants and rioters. So it is right if humiliation becomes their most prominent appearance on the day of vengeance. ${ }^{10}$ Khasyi ${ }^{`} \mathrm{in}$ comes from the typical word 'a-yakhsya' $u-k h u s y \bar{u}$ 'an which means submissive, low, and submissive.

The verse explains the closeness of their position from the torment they have faced. Allah says: and you whoever is present in the arena will see also those wrongdoers, faced from moment to moment to him the angels face them to the place of torture and when they are bowed down due to humiliation, and continue they continually see with a clandestine view that is stealing a glance for fear of torture that will soon befall.

\subsection{Relevance of the Charged Paragraph Kinesik and Communication}

\section{Abasa (surly)}

Surly in surah asa The age of the first verse is a spontaneous communication from the Prophet through the expression on his face. In this verse it is clearly illustrated how the process of communication of the Prophet's body language through the phrase "he Muhammad was surly and turned away." The emotional atmosphere of the Prophet s.a.w which was not pleasing to Abdullah Ibn Maktum's actions was illustrated by the expression on his face. Viewed from the function of nonverbal communication in this case body language communication, the face of the Prophet Muhammad s.a.w is a complementary message in which the facial expressions are complementary to the Prophet's displeasure with the actions of Abdullah Ibn Ummi Maktum.

2. Taqalluba wajhika Fissamā '(your face looks up to the sky).

The event in this verse becomes history that has a very important position in Muslim life. As explained by the explanation this verse tells about how the beginning of the change of direction of the Muslim direction from Baitul Maqdis to Baitullah. The Qur'an enshrines the body language of the Prophet when pleading with Allah regarding the Qibla of the Muslims, as explained by the interpreter, this is clearly revealed through his word "Indeed, we (often) see your face looking up at the sky." is the communication of the prophet's body language to God in the form of hope and complaints from the Prophet to Allah. The hope of the Prophet is granted by Allah SWT through his words: So really we will turn you to the qibla that you like. turn your face toward the Holy Mosque. and wherever you are, turn your face towards him.

\section{Antughmidhū (squinting)}

Eye behavior or eyesight in communication science studies is termed okulesika (oculesics). There is a lot of literature that says that the eye is a part of the face that very much gives a signal and the most powerful influence in the communication process. Among the body parts found on the face, the eyes are considered the most expressive. Although physically the human eye looks similar, but very many different meanings are reflected in someone's eyes in different situations. Verse expressions Squinting is a sign of a reluctance or displeasure with something. In this case Mufassir explained that the expression of squinting

${ }^{10}$ M. Quraish Shihab, Tafsir Al-Misbah...Volume 12, p. 517. 
was a sign of expression as well as a warning to those who gave away their assets so that they were not given away by the bad ones.

4. Wajhuhū Muswaddan (black; red goes out his face)

The black and red face is a form of expression of the communication of the body language of the polytheists because it holds back anger and feelings of shame and feels despised blessed with women. Theoretically body language communication occurs naturally which is a reflection of feelings and emotions. In this case the feeling of dislike and contempt experienced by the polytheists of ignorance is spontaneously conveyed through their body language messages, namely through a black and red face.

5. Watarāhum yu'radhūna 'alaihā khāsyi'īn (and you will see them facing hell in submission).

Their lowered posture and silence is a reflection of their emotions in the form of despair, fatigue, and humility and fear of the torment that will befall them. There are two categories of body language found in this verse, the posture of being bowed and the behavior of the eye in the form of a secret view. According to Michael Argley, one form of contact or eye view that is universally applicable is to turn eye contact by shifting gazes or downward gazes in this case, including the attitude of looking down, considered to be someone who is willing to surrender. ${ }^{11}$ Selian's other research conducted by Tomkins and Carter (1994) which develops 8 feelings that can be seen from body language, one of which is feeling embarrassed and humiliated can be seen from the view of the eyes down or down. ${ }^{12}$ This is in line with what was explained by Mufassir described earlier.

\section{Conclusion}

The verses of the Qur'an which describe the communication process explicitly illustrate that potential kinesic aspects occur throughout the period in the process of human interaction. The Al-Qur'an contains information about kinesik processes that occur spontaneously, naturally, and conditionally. This shows that the presentation of kinesik verses is relevant to proceed in the global era, even throughout modern human life.

\section{References}

A. Muis, Komunikasi Islami, Bandung: Remaja Rosdakarya, 2001.

Ahmad Warson Al-Munawwir, Kamus Al-Munawwir Arab-Indonesia, Yogyakar-ta: Pondok Pesantren "al-Munawwir", t.t.

Al-Dimashqi, 'Abd al-Fida Ismā'il Ibn Kathīr, Tafsir Ibn Kathīr, Juz 17, terj. Bah-run Abu Bakar, Bandung: Sinar Baru Algen-sindo, 2004.

Ali Lilioweri, Komunikasi Serba Ada Serba Makna, Jakarta: Kencana, 2011.

Ali, Abdullah Yusuf, The Holy Quran: Text, Translation and Commentary, Kuala Lumpur: Islamic Book Trust, 2003.

Argyle, Michael, The Psikology of Interpersonal Behavior, London: Penguin, 1967.

Bakr, Syamsuddin Muhammad Ibn Abi, Anatomi Tubuh dalam Al-Qur'an: Tafsir Tematik Klasik, terj. Tim Redaksi Nalar, Jakarta: Intimedia Ciptanusantara, t.t.

\footnotetext{
${ }^{11}$ Gordon R. Wainwright, Body Language...p. 21.

${ }^{12}$ Muhammad Budyanta, Komunikasi Organisasi... p. 141-142
} 
Birdwhistell, Ray L., Introduction to Kinesics: An Annotation System for Analysis of Body Motion and Gesture, Washington: Department of State, Foreign Service Institute, 1952.

Danesi, Marcel, "Kinesics," dalam Keith Brown (ed.), Encyclopedia of Language and Linguistics, ed. 2, Boston: Elsevier, 2006.

Deddy Mulyana, Ilmu Komunikasi: Suatu Pengantar, Bandung: Remaja Rosda-karya, 2009.

Dissayanake, Wimal (Ed), Communication Theory: The Asian Perspectives, Si-ngapore: Mass Communication Research and Information Centre, 1988.

E. Sulistiany, Pengantar Metode Penelitian Kualitatif, Surabaya: Usaha Nasional, 1999.

Ellys Lestari Pambayun, Communication Quotient: Kecerdasan Komunikasi da-lam Pendekatan Emosional dan Spiritual, ed. Adriyani Kamsyach, Ban-dung: Remaja Rosdakarya, 2012.

Eriyanto, Analisis Isi: Pengantar Metodologi untuk Penelitian Ilmu Komunikasi dan Ilmuilmu Sosial Lainnya, Jakarta: Kencana, 2011.

Fisk, John, Pengantar Ilmu Komunikasi, Jakarta: Rajagravindo Persada, 2012.

Gudykunst, William B. dan Young Yun Kim, Communcating With Strangers: An Approach to Intercultural Communication, New York: McGraw-Hill, 1992.

Hafied Cangara, Pengantar Ilmu Komunikasi, Jakarta: Rajagrafindo Persada, 2007.

Hans, Anjali dan Emmanuel Hans, "Kinesics, Haptics and Proxemics: Aspects of NonVerbal Communication," dalam Journal of Humanities and Social Science, vol. 20.

Harjani Hefni, Komunikasi Islam, Bandung: Prenadamedia Group, 2015.

Hussain, et.al. Dua Puluh Lima Soal Jawab Mengenai Komunikasi Islam, Serdang Selangor: Pusat Pengembangan dan Pendidikan Lanjutan Universiti Pertani-an Malaysia, 1990.

Ibnu Hamad, "Kata Pengantar," dalam Brent D. Ruben dan Lea P. Stewart, Komu-nikasi dan Perilaku Manusia, terj. Ibnu Hamad, Jakarta: RajaGrafindo Per-sada, 2014.

Jalaluddin Rakhmat, Psikologi Komunikasi, ed. Tjun Surjaman, cet. 21, Bandung: Remaja Rosdakarya, 2001.

M. Hasan Basry, Kamus Umum Indonesia-Aceh, (t.t.: Yayasan Cakra Daru, 1994.

M. Quraish Shihab, Tafsīr Al-Misbāh: Pesan, Kesan dan Keserasian Al-Qur'an, vol. 15, cet. 5, Jakarta: Lentera Hati, 2002.

M. Tata Taufik, Etika Komunikasi Islam, ed. Beni Ahmad Saebani, Bandung: Pus-taka Setia, 2012.

M. Yaniyullah Delta Auliya, Melejitkan Kecerdasan Hati dan Otak Menurut Pe-tunjuk AlQur'an dan Neurologi, Jakarta: RajaGrafindo Persada, 2005.

Manna' al-Qaẓan, Mabāhis fì 'Ulm Al-Qur'ān, ttt: Mansyurāt al-'Așrul al-Hadì̀, 1973.

Mohd. Yusof Hussin, "Islamization of Communication Theory”, Media Asia, Vol. 13, 1986.

Morissan, Teori Komunikasi Individu Hingga Massa, Jakarta: Kencana Prenada Media Group, 2013.

Mowlana, Hamid, "The New Global Order and Cultural Ecology", Media, Cultu-re, and Society, Jilid 15, No. 1, 1993.

Nina Winangsih Syam, Komunikasi Transendental: Perspektif Sains Terpadu, ed. Adriyani Kamsyach, Bandung: Remaja Rosdakarya, 2015.

Pease, Allan, Bahasa Tubuh: Bagaimana Membaca Pikiran Seseorang Melalui Gerak isyarat, terj. Arum Gayatri, Jakarta: Arcan, 1987. 
Rosyadi Ruslan, Metode Penelitian Public Relation dan Komunikasi, Jakarta: Ra-ja Grafindo Persada, 2004.

Ruben, Brent D. dan Lea P. Ste-wart, Komunikasi dan Perilaku Manusia, terj. Ib-nu Hamad, cet. 2, Jakarta: Rajagrafindo Persada, 2014.

Samovar, Larry A. dan Richard E. Porter, Communication between Cultures, Bel-mont, California: Wadsword, 1991.

Setio Budi H.H. et.al. Communication Review: Catatan Tentang Pendidikan Ko-munikasi di Indonesia, Jerman, dan Australia, ed. Setio Budi H.H., Yog-yakarta: Program Studi Ilmu Komuni-kasi Universitas Atma Jaya, 2012.

Sugeng Leksono, Metode Penelitian Komunikasi Kualitatif, Malang: Intrans Pu-blishing, 2015.

Syukur Kholil, Komunikasi Islami, Bandung: Citapustaka Media, 2007.

Taufik Pasiak, Revolusi IQ/EQ/SQ: Antara Neurosains dan Al-Qur'an, Bandung: Mizan, 2003.

Taufik Pasiak, Unlimited Potency of the Brain, Bandung: Mizan, 2009.

Thabathaba'i, Al-Mizan, juz 20, Beirut, Lebanon: Muassasah al-A 'lamiy, t.t.

Tim Redaksi Kamus Besar Bahasa Indonesia, Kamus Besar Bahasa Indonesia, ed. 3, cet. 4, Jakarta: Balai Pustaka, 2007.

Tim Syaamil Al-Qur'an, Hijaz: Terjemah Tafsir Perkata, Bandung: Syaamil Qur-an, t.t.

Trenholm, Sarah dan Arthur Jensen. Interpersonal Comunication, ed. 2, Belmont, California: Wadsword, 1992.

Wenburg, Jonn R. dan Wiliam W. Wilmot, The Personal Communication Pro-cess, New York: John Wiley and Sons, 1973.

Yayasan Penyelenggara Penterjemah Al-Qur'-an, Al-Qur'an dan Terjemahnya, Jakarta: Departemen Agama RI Proyek Pengadaan Kitab Suci Al-Qur'an, 1984.

Yin, Robert K., Studi Kasus (Desain dan Metode), ed. revisi, Bandung: Remaja Rosdakarya, 2002. 